\title{
Problems of development of environmental initiatives of the public and business in cooperation with municipal management
}

\author{
Anna Balabanova, ${ }^{1, *}$, and Nadezhda Keschyan ${ }^{1}$ \\ ${ }^{1}$ Sochi State University, st. Plastunskaya, 94, 354000, Sochi, Russia
}

\begin{abstract}
The article studies the problems of the public and business in the field of development of environmental initiatives and the problems of interaction with the municipal environmental management. The research was conducted in the tourist city of Russia, where ecology is of great importance for the development of tourism. The regulatory legal acts of the city and the municipal environmental management system were researched. A survey was also conducted of public organizations and businesses, which in the city became the initiators and participants of environmental projects. The research confirmed that there are problems highlighted by the public and business in the development of environmental initiatives in collaboration with municipal environmental management. Some problems create obstacles to the development of initiatives and reduce the level of business's desire to spend their time and resources in the field of ecology. The initiatives of business and the public were ahead of the legislation both at the state level and at the municipal level. These initiatives made it possible to organize work to promote the environmental literacy of the population and separate waste collection. The absence of a system of interaction with organizations involved in environmental activities and responsible for this system of the post, the lack of educational work in the field of environmental literacy of the population and representatives of the city administration, the lack of a single information resource in the field of ecology and environmental initiatives of the city have a negative impact on the number of city initiatives in the field of ecology., insufficient education and clarification in the implementation of state legislation in the field of ecologic and separate waste collection.
\end{abstract}

\section{Introduction}

The interaction of the state and business in the environmental sphere is currently underdeveloped. Nevertheless, the further development of this type of partnership is relevant and promising $[1,2]$.

\footnotetext{
*Corresponding author: annabalabanovasochi@gmail.com
} 
In recent years, there has been a trend around the world in increasing cooperation between government and business. The interaction of government and business is the driving force behind the development of society [3, 4, 5].

One of the most important areas is cooperation in solving environmental problems between government bodies, business entities, and public organizations. "The conflict between urban development and environmental protection must be resolved to achieve the goal of sustainable development" [6].

"The production of municipal solid waste has increased markedly in recent years due to the growing population of the planet and rapid urbanization. In addition, its poor management and improper disposal are a global problem, as they create environmental problems in urban ecosystems. Waste management problems were significantly inhibited due to lack of quality data" [7].

The current practice of applying social partnership mechanisms is based on the conclusion of agreements between authorities and private businesses, which formulate the rights and obligations of both parties [8]. Sometimes, such organizations are joined by public organizations and associations interested in implementing socially significant social projects and ready to contribute to the achievement of practical results [9]. Along with the reduction of negative environmental impact indicators, the rational use of water, biological and other resources, the interaction of enterprises on improving the environmental situation in the territory was determined not only with authorities at various levels but also with the public and other non-profit associations. "Joint management can be considered a partnership of knowledge. Different levels of an organization, from local to international, have comparative advantages in generating and mobilizing knowledge gained at different scales. Linking organizations provide a forum for the interaction of these various types of knowledge and coordination of other tasks that ensure cooperation: access to resources, pooling of various participants, building trust, conflict resolution and networking" [10]. "Joint management has gained fame due to its sustained interest in the sharing of natural resources" $[11,12]$.

The development of interaction between government and business will improve the quality of life of the population and the ecological well-being of the territory.

\section{Materials and Methods}

The article used the method of theoretical analysis and synthesis of scientific and methodological literature, regulatory documents, observation, methods of mathematical analysis and statistics.

The research was conducted in the tourist city of Russia, where ecology is of great importance for the development of tourism. The period of the study is from autumn 2018 to summer 2019. During the study, a survey was conducted of employees of the Department of Environmental Protection, Forest Park, Agriculture and Industry of the city administration. The regulatory legal acts of the city and the municipal environmental management system were studied.

A survey was also conducted of public organizations and businesses, which in the city became the initiators and participants of environmental projects. The survey was conducted in electronic form. The survey was attended by 31 organizations operating in the field of ecology in the city of Sochi and participating in educational work.

The publications were also a source of data for analysis:

- Reports and plans of the Public Environmental Council under the Head of the City of Sochi (Municipal Administration of the City of Sochi, Sochi, 2017);

- "Krasnodar region in numbers". 2018. (Territorial body of the Federal State Statistics Service for the Krasnodar Territory. Krasnodar, 2019); 
- The project "Environmental program of the Municipal Formation of the resort city of Sochi for 2015-2030";

- Decree of the Sochi city administration No. 3237 "On the permanent public environmental council under the Head of the city of Sochi";

- Decision of the Sochi City Assembly of No. 214 "On approval of the target program» Development of children's local history and ecological tourism in the city of Sochi" for 2016".

- Decree of January 20, 2017 n 48 "On approval of the collection procedure (including separate) of solid municipal waste in the territory of the Krasnodar Territory";

- The Federal Law "On Production and Consumption Wastes" dated June 24, 1998 N 89$\Phi 3$.

The research was conducted in order to identify problems of the public and business in the field of development of environmental initiatives and problems of interaction with the municipal environmental management.

For the ecological development of the territory, cooperation and participation of not only state and municipal government representatives are important, but also the participation of all economic participants: the public, business, and citizens.

\section{Results}

Consider the organizations that accepted participating in the research. More than half of the organizations in the city that are engaged in environmental initiatives are non-profit organizations (Fig. 1).

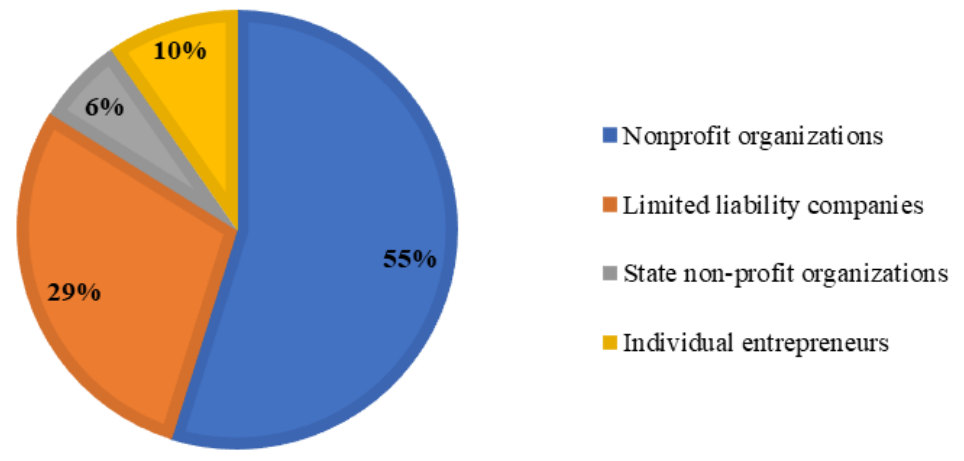

Fig. 1. Structure of organizations participating in the study.

The main directions of environmental initiatives of participating organizations in the study:

- volunteer activities;

- public control;

- legal activity;

- environmental education and awareness;

- environmental assessment;

- collection, removal, recycling, sorting, processing of secondary raw materials;

- collection, removal, recycling, sorting, processing of waste;

- the creation of organic fertilizers;

- manufacture of containers for separate waste collection.

In 2019, the second survey of respondents was conducted, which showed a decrease in the number of organizations that participate in environmental initiatives. The number of organizations involved in environmental activities decreased by $29 \%$ (Fig. 2). 


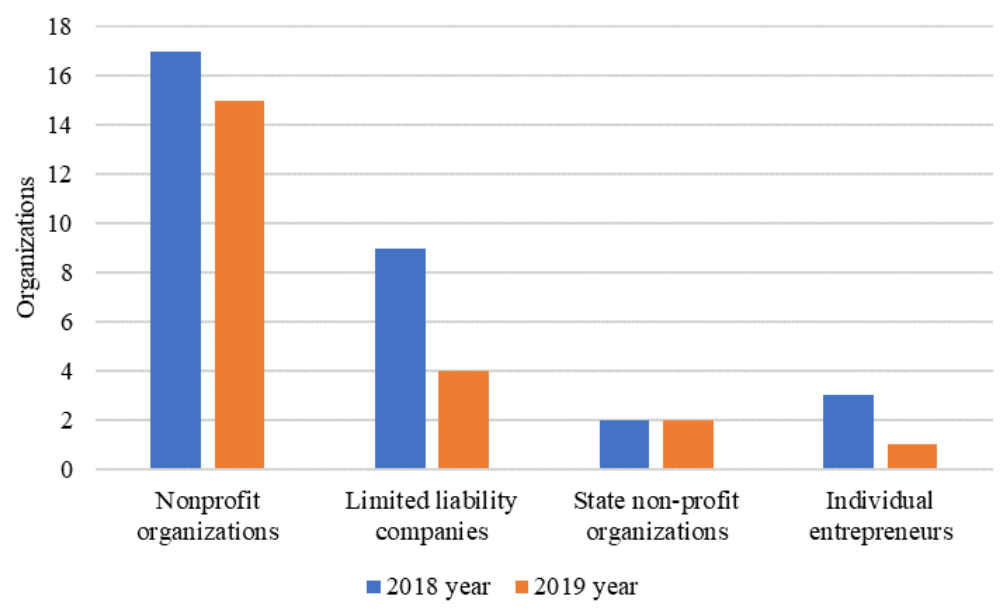

Fig. 2. Dynamics of the number of organizations engaged in environmental activities in 2018-2019 that took part in the study.

As a result of the analysis, processing of questionnaires and survey results, it was found that $80 \%$ of respondents carry out activities in the field of environmental education of the population (Fig. 3).

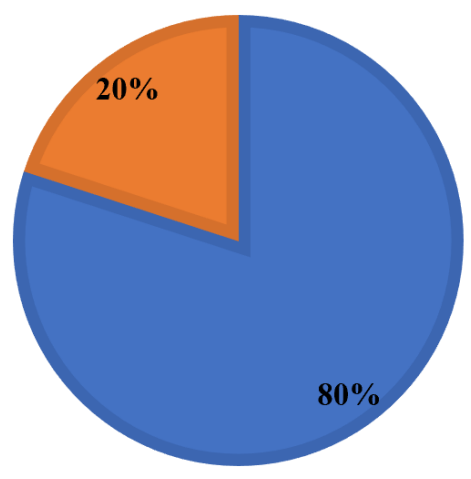

- Organizations involved in the promotion of ecology n Organizations not involved in the promotion of ecology

Fig. 3. Distribution of opinions of respondents regarding their activities in the field of environmental promotion.

The main structural unit of the municipal government, which deals with the ecology of the city, is the Department of Environmental Protection, Forest Park, Agriculture and Industry of the city administration. Of the 31 organizations surveyed, only $20 \%$ have ever interacted in their work with the Department of Environmental Protection, Forest Park, Agriculture and Industry of the city administration of Sochi. The research also found that all $70 \%$ of organizations involved in the promotion of ecology would like to interact with the department. $10 \%$ of organizations do not want to interact with the city administration in their work (Fig. 4). 


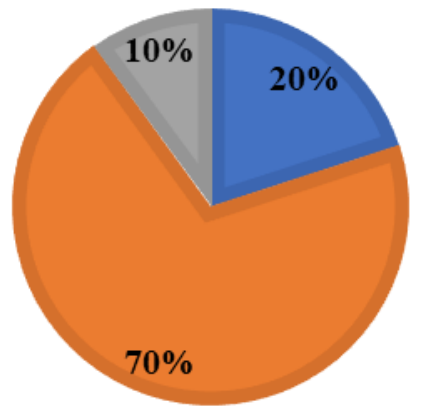

- Organizations interacting with the department Organizations wishing but not interacting with the
department

Organizations that do not want to and do not interact with the department

Fig. 4. Distribution of opinions of respondents regarding interaction with the Department of Environmental Protection, Forest Park, Agriculture and Industry of the city administration.

The results of the answer to the question: "In your opinion, what are the strengths for activities in the field of development of environmental initiatives and cooperation with territorial organizations in the Sochi Department of Environmental Protection, Forest Park, Agriculture, and Industry?" are presented in table 1:

Table 1. Results of the answer to the question: "What strengths for the activity in the field of development of environmental initiatives and cooperation with territorial organizations, in your opinion, does the Department of Environmental Protection, Forest Park, Agriculture and Industry of the city administration have?".

\begin{tabular}{|l|c|c|}
\hline № & Strengths & Частота ответов \\
\hline 1. & Administrative resources (transport, premises, materials, etc.) & $80 \%$ \\
\hline 2. & Regulatory support of activities & $25 \%$ \\
\hline 3. & Financial resources & $70 \%$ \\
\hline 4. & $\begin{array}{c}\text { The opportunity to participate in state and municipal programs in } \\
\text { the field of development of environmental initiatives and } \\
\text { cooperation with organizations of the territory }\end{array}$ & $40 \%$ \\
\hline 5. & The possibility of interaction with other municipal and state bodies & $50 \%$ \\
\hline
\end{tabular}

The results of the answer to the question: "What weaknesses in the activity in the field of development of environmental initiatives and cooperation with territorial organizations, in your opinion, does the department of environmental protection, forest park, agriculture, and industry of the city administration have?" are presented in table 2 :

Table 2. Results of the answer to the question: "What weaknesses in the activity in the field of development of environmental initiatives and cooperation with territorial organizations, in your opinion, does the department of environmental protection, forest park, agriculture and industry of the city administration have?".

\begin{tabular}{|l|c|c|}
\hline № & Weaknesses & The answers \\
\hline 1. & Lack of labor & $25 \%$ \\
\hline 2. & A small amount of financial resources & $40 \%$ \\
\hline 3. & The lack of environmental education in the tasks of the department & $90 \%$ \\
\hline 4. & $\begin{array}{c}\text { Unorganized interaction with organizations engaged in educational } \\
\text { activities }\end{array}$ & $70 \%$ \\
\hline
\end{tabular}




\begin{tabular}{|l|c|c|}
\hline № & Weaknesses & The answers \\
\hline 5. & Lack of a single information resource of the department & $40 \%$ \\
\hline 6. & Little information about the activities of the department, contact details & $80 \%$ \\
\hline 7. & $\begin{array}{c}\text { Little information about the possibility of cooperation with the } \\
\text { department in the field of promoting ecology }\end{array}$ & $60 \%$ \\
\hline
\end{tabular}

Also, respondents identified problems in the organization of separate garbage collection, which they would like to solve together with the municipal administration:

- allocation of land for sorting garbage on a long-term lease;

- fixing the responsible person for cooperation on the implementation of a separate fee in the city administration and in the department of municipal services;

- installation of containers for separate collection of garbage at municipal sites;

- definition of collection points for separate collection in each district of the city;

- inappropriate waste that residents throw into a container for bottles, and the management of the special joint-stock company "Special Cleaning Service of the City" requires a re-payment, ignoring the fact that residents have already paid for this removed waste.

At present, the leadership of the Department of Municipal Economy and the special joint-stock company "Special Cleaning Service of the City" have moved away from solving this issue. The city administration explains the reason for the low activity in this matter by the resolution of January 20, 2017 No. 48 on the approval of the collection procedure (including separate) of solid municipal waste in the territory of the Krasnodar Territory, according to which the regional operator will deal with separate garbage, and local authorities will be removed from resolving issues of cleaning the city and responsibility for the sanitary condition of the city.

According to the decree and Federal Law-89 "On Production and Consumption Wastes", a separate collection of waste will be introduced throughout the Russian Federation until 2027.

As a result of the questionnaire, respondents rated interaction with the city administration in the field of supporting environmental initiatives at 5.5 points on a 10 point scale.

\section{Discussion}

After analyzing the answers of the respondents to the question: "In your opinion, what are the strengths for activities in the development of environmental initiatives and cooperation with territorial organizations in the Department of Environmental Protection, Forest Park, Agriculture and Industry of the city administration?", we can conclude that the department can actively collaborate with organizations in the field of environmental education through the administrative resources it possesses.

Also, financial resources and the ability to develop municipal programs are important. Less important for heads of organizations are experienced in the activities of department employees, as well as regulatory support for activities. (tab. 1).

It can also be concluded that the department needs to include environmental education in the tasks of the department, as well as to establish interaction with organizations involved in environmental activities. The lack of labor resources is not considered a weakness, as organizations are ready to meet and help in their work, as this is in their interests (Table 2).

The research confirmed that there are problems highlighted by the public and business in the development of environmental initiatives in collaboration with municipal 
environmental management. Some problems create obstacles to the development of initiatives and reduce the level of business's desire to spend their time and resources in the field of ecology. The initiatives of business and the public were ahead of the legislation both at the state level and at the municipal level. These initiatives made it possible to organize work to promote the environmental literacy of the population and work with a separate collection of garbage.

For high-quality environmental management of the territory, cooperation and participation of not only state and municipal government representatives are important, but also the participation of all economic participants: the public, business, and citizens.

The process of interaction between the municipal government and business in the field of environmental initiatives may be suspended due to a lack of understanding of changes in legislation [13].

\section{Conclusions}

By combining the results of the study, the analysis of the regulatory framework of the city in this area, as well as the results of the second survey of respondents, we can conclude: the organization of the interaction of the city administration with the public and business representatives has a significant impact on the number of environmental initiatives.

The problems of environmental management in the city that negatively affect the number of environmental initiatives are:

- lack of a system of interaction with organizations involved in environmental activities and responsible for this system of position.

- lack of educational work in the field of environmental literacy of the population and representatives of the city administration;

- lack of a single information resource in the field of ecology and environmental initiatives of the city;

- insufficient education and clarification in the implementation of state legislation in the field of ecology and a separate collection of garbage.

In the future, it is necessary to research effective models of interaction between the municipal government and the public in the field of supporting environmental initiatives, the degree of influence of environmental literacy of the process participants and the population.

\section{References}

1. S. Benn, D. Dunphya, A. Martinb, J. of Envir. Man., 90 (4), 1567-1575 (2009)

2. L. Potricha, M. N. Cortimiglia, J. Fleith de Medeiros, J. of Envir. Man., 243, 273-286 (2019)

3. N., Ahmeda, M.N., Islam, A.S., Tuba, M.R.C., Mahdy, M., Sujauddin, J. of Envir. Man., 248 (15), 109253 (2019)

4. N.M., Todaro, F., Testa, T., Daddi, F., Iraldo, J. of Envir. Man. 247, 804-815 (2019)

5. M., Smith, B., Ambrose-Oji, J. of Envir. Man., 233, 757-767 (2019)

6. Y., Yang, W., Li, J. of Envir. Man., 243, 463-471(2019)

7. A., Singh, J. of Envir. Man., 243, 22-29 (2019)

8. B., Sæther, A., Isaksen, A., Karlsen, Geoforum, 42 (3), 373-381 (2011)

9. R., Holifield, K.C., Williams, J. of Envir. Man., 230, $422-433$ (2019)

10. F., Berkes, J. of Envir. Man., 90 (5) 1692-1702 (2009) 
11. R. Plummer, D. Fennell, J. of Envir. Man., 85 (4), 944-955 (2007)

12. S., Bautista, J., Llovet, A., Ocampo-Melgar, A., Vilagrosa, J. of Envir. Man., 195 (1), 35-45 (2017)

13. N.A., Kezhyan, A.O., Balabanova, T.G., Borisova, E.N., Hachemisova, The environmental policy implementation of the city of Sochi. Int. Scie. Conf.: Top. Prob. of arch., civil eng. and envir. Ec. TPACEE 2018. E3S Web of Conf. 91 (121) (2019) 